\title{
PENGARUH PERTUMBUHAN EKONOMI TERHADAP PENURUNAN KEMISKINAN DI PROVINSI JAMBI TAHUN 2009-2013
}

\author{
Ambok Pangiuk \\ Fakultas Ekonomi dan Bisnis Islam UIN STS Jambi \\ Ambokpangiuk1975@gmail.com
}

\begin{abstract}
Abstrak
Penelitian ini bertujuan untuk mengetahui pengaruh pertumbuhan ekonomi terhadap pengurangan kemiskinan di provinsi Jambi pada tahun 2009-2013. Metode yang digunakan dalam penelitian ini adalah metode pendekatan kuantitatif. Analisis data yang digunakan adalah rumus pendapatan dan analisis statistik regresi sederhana menggunakan variabel independen yang meliputi pertumbuhan ekonomi terhadap variabel dependen kemiskinan. Hasil penelitian menunjukkan bahwa pertumbuhan ekonomi tidak berpengaruh signifikan terhadap kemiskinan. Faktor-faktor ini volume pertumbuhan ekonomi tidak memiliki pengaruh paling dominan terhadap kemiskinan karena memiliki nilai terbesar dibandingkan dengan nilai pertumbuhan. Hasil analisis yang menyatakan bahwa pembangunan dan pertumbuhan ekonomi di provinsi Jambi persentase tertinggi pertumbuhan ekonomi tahun 2009-2013 pada tahun 2011 adalah 8,54\%, sedangkan persentase terendah pada tahun 2009 adalah $5,57 \%$. Berdasarkan perkembangan kemiskinan di provinsi Jambi, persentase tertinggi tingkat kemiskinan pada tahun 2009-2013 adalah tahun 2013 yaitu 31,78\% dan persentase terendah tahun 2011 adalah 26,04\%. Dampak pertumbuhan ekonomi terhadap kemiskinan di Provinsi Jambi, dimana variabel pertumbuhan ekonomi tidak berpengaruh dan tidak signifikan terhadap variabel kemiskinan atau nilai kesatuannya terhadap kemiskinan adalah negatif. Ini menunjukkan bahwa pertumbuhan ekonomi tidak berpengaruh terhadap kemiskinan di Provinsi Jambi.
\end{abstract}

Kata Kunci: Pertumbuhan Ekonomi, Pengurangan Kemiskinan, Jambi

\section{PENDAHULUAN}

Pembangunan dilaksanakan mewujudkan kemakmuran masyarakat melalui pengembangan perekonomian mengatasi berbagai permasalahan pembangunan dan 
sosial kemasyarakatan seperti pengangguran dan kemiskinan. Selain pertumbuhan ekonomi, salah satu aspek penting untuk melihat kinerja pembangunan adalah seberapa efektif penggunaan sumber-sumber daya yang ada sehingga lapangan kerja dapat menyerap angkatan kerja yang tersedia. Pertumbuhan ekonomi yang semakin meningkat berarti produksi barang/jasa yang dihasilkan meningkat. Dengan demikian diperlukan tenaga kerja semakin banyak untuk memproduksi barang/jasa tersebut sehingga kemiskinan berkurang dan semakin menurun. ${ }^{1}$

Propinsi Jambi adalah merupakan salah satu propinsi yang kaya akan sumber daya alamnya yang tidak dimiliki oleh Propinsi lain. Tapi sayangnya pemanfaatan sumber daya alam di Propinsi Jambi masih belum maksimal. Jambi merupakan salah satu Propinsi berkembang yang dimana permasalahan utama yang dihadapi sama seperti Propinsi berkembang lainnya yaitu masalah tingginya tingkat kemiskinan. Dari tahun ke tahun, masalah jumlah kemiskinan di Propinsi Jambi ini kian bertambah. Belum ada solusi yang ampuh untuk mengatasi tingginya angka kemiskinan sampai saat ini. Pengadaan lapangan kerja saja dirasa tidak cukup untuk menekan tingginya angka kemiskinan di Propinsi kita. ${ }^{2}$

Pada awalnya upaya pembangunan Propinsi Jambi sedang berkembang di identikkan dengan upaya meningkatkan pendapatan perkapita. Dengan meningkatnya pendapatan perkapita diharapkan masalah-masalah seperti pengangguran, kemiskinan, dan ketimpangan distribusi pendapatan yang dihadapi Propinsi Jambi dapat terpecahkan. Namun kenyataanya tidak demikian. Hal ini terjadi karena angka-angka yang ditunjukkan oleh pendapatan domestik dan daerah bruto kurang peka dalam mengungkapkan masalah-masalah kemiskinan. Apalagi ditambah kenyataan bahwa jurang perbedaan antara kelompok kaya dan miskin yang semakin melebar seiring dengan pesatnya pertumbuhan ekonomi tersebut. Kenyataan yang terjadi, dimana kondisi Muaro jambi dengan tingkat kemiskinan yang relatif rendah dibandingkan dengan Kabupaten lainnya, tetapi tingkat kemiskinan paling tinggi di Provinsi Jambi. Berdasarkan data BPS, tahun 2009 tingkat kemiskinan terbuka di Kota Jambi (54.9\%) relatif lebih tinggi di bandingkan Kabupaten Tanjung Jabung Barat (34.0\%) dan di Tanjung Jabung Timur (28.8\%). Lebih tinggi dari kabupaten Merangin (27.5\%) Kabupaten Sarolangun (25.2\%), lebih tinggi dari kabupaten Kerinci (24.1\%), di Batang Hari (23.2\%), Tebo (16.2\%) Bungo (13.7\%) dan Muaro Jambi (13.7\%). ${ }^{3}$

Berbagai pandangan tentang pertumbuhan ekonomi yang merupakan masalah ekonomi jangka panjang. Definisi dari pertumbuhan ekonomi itu sendiri adalah perkembangan ekonomi yang berlaku dari waktu ke waktu dan menyebabkan pendapatan daerah yang riil semakin berkembang. Pertumbuhan

\footnotetext{
${ }^{1}$ Lincolin Arsyad., Prospek Ekonomi Indonesia Jangka Pendek: Sumber Daya, Teknologi dan Pembangunan, Jakarta, Gramedia, 2001), hlm. 13.

${ }^{2}$ Data dokumentasi Badan Puasat Statistik Jambi. BPS.go.id akses 20 September 2012.

${ }^{3}$ Data dari Badan Pusat Statistik dan Informasi Kemiskinan Kabupaten/Kota Propinsi Jambi tahun 2012.
} 
ekonomi sebagian besar yang diukur dari kenaikan besarnya pendapatan daerah pada periode tertentu. Tingkat pertumbuhan ekonomi menunjukkan persentase kenaikan pendapatan daerah riil pada suatu tahun tertentu dibandingkan dengan pendapatan daerah riil pada tahun sebelumnya. Pendapatan nasional sebagai nilai barang-barang dan jasa yang dihasilkan suatu Provinsi tersebut dihitung secara riil atau menurut harga tetap pada harga-harga di tahun tertentu yang berbeda dengan tahun dimana produksi nasionalnya dihitung. Pertumbuhan perekonomian diartikan sebagai kenaikan produk domestik regional bruto (PDRB) tanpa memandang apakah kenaikan itu lebih besar atau lebih kecil dari tingkat pertumbuhan penduduk atau apakah perubahan struktur ekonomi terjadi atau tidak. Alat pengukuran pertumbuhan perekonomian dapat dilihat pada kenaikan produk domestik regional bruto. Perhitungan produk domestik regional bruto berbagai macam caranya, menurut BPS tahun 2009, menyebutkan bahwa pengertian produk domestik regional bruto dapat dilihat dari tiga sisi yaitu produksi, pendapatan dan pengeluaran. ${ }^{4}$

Secara umum diketahui bahwa pertumbuhan ekonomi merupakan indikator yang lazim digunakan oleh suatu provinsi untuk melihat kemajuan atau kemampuan provinsinya. Pengentasan kemiskinan telah menjadi tujuan pembangunan yang fundamental sehingga menjadi sebuah alat ukur untuk menilai efektivitas berbagai jenis program pembangunan. Pertumbuhan ekonomi dapat menjadi instrumen yang sangat berpengaruh dalam penurunan kemiskinan pendapatan, sehingga dibutuhkan cara-cara yang tepat dalam mengkaji dampak kemiskinan terhadap pertumbuhan ekonomi. Dibandingkan dengan kabupaten lain, pertumbuhan ekonomi di Propinsi Jambi tidak rendah. ${ }^{5}$

Pertumbuhan ekonomi dapat menunjukkan sejauhmana aktivitas perekonomian akan menghasilkan tambahan pendapatan masyarakat pada suatu periode tertentu. Oleh karena itu, pada dasarnya aktivitas perekonomian adalah suatu proses penggunaan faktor-faktor produksi untuk menghasilkan output, maka proses ini pada gilirannya akan menghasilkan suatu aliran balas jasa terhadap faktor produksi yang dimiliki masyarakat. Indikator yang digunakan untuk mengukur pertumbuhan ekonomi adalah tingkat pertumbuhan Produk Domestik Bruto (PDB). Ada beberapa alasan yang mendasari pemilihan pertumbuhan ekonomi menggunakan Produk Domestik Bruto (PDB) bukan indikator lainnya di antaranya adalah PDB merupakan jumlah nilai tambah yang dihasilkan oleh seluruh aktivitas Produksi di dalam perekonomian, hal ini berarti peningkatan PDB juga mencerminkan peningkatan balas jasa kepada faktor-faktor produksi tersebut. Dalam lingkup daerah, definisi pertumbuhan ekonomi daerah sama saja dengan pertumbuhan ekonomi secara nasional hanya saja lokasi atau wilayahnya dipersempit menjadi di wilayahnya masing-masing dan disesuaikan dengan lingkungan operasionalnya, seperti provinsi, kota atau kabupaten. ${ }^{6}$

\footnotetext{
${ }^{4}$ http://daps.bps.go.id/File diakses tanggal 26 Oktober 2013.

${ }^{5}$ Data dari Badan Pusat Statistik dan Informasi Kemiskinan Kabupaten/Kota Propinsi Jambi tahun

2012.

${ }^{6}$ N. Gregori Mankiw, Teori Makro Ekonomi, Jakarta: Gelora Aksara Pratama, 2007, hlm. 65.
} 
Pertumbuhan ekonomi wilayah adalah pertambahan pendapatan masyarakat secara keseluruhan yang terjadi pada wilayah tersebut, yaitu kenaikan seluruh kenaikan nilai tambahyang terjadi. Perhitungan Pendapatan Wilayah pada awalnya dibuat dalam harga berlaku. Namun, agar dapat melihat pertambahan dari satu kurun waktu ke kurun waktu berikutnya, harus dinyatakan dalam nilai riil, artinya dalam harga konstan. Dalam penerapannya harus dikaitkan dengan ruang lingkup wilayah operasinya, misalnya daerah tidak memiliki wewenang untuk membuat kebijakan fiskal dan kebijakan moneter, wilayah lebih terbuka dalam pergerakan orang dan barang. Secara ilmu ekonomi makro dan ekonomi pembangunan, adanya istilah ekspor dan impor. Sedangkan, berdasarkan ekonomi regional atau wilayah diartikan perdagangan dengan luar wilayah. ${ }^{7}$.

Untuk melihat ukuran Pertumbuhan ekonomi daerah maka yang sering dipergunakan adalah Produk Domestik Regional Bruto (PDRB), yaitu jumlah nilai tambah bruto yang dihasilkan oleh seluruh sektor perekonomian di suatu wilayah. Sedangkan PDRB per Kapita adalah pendapatan per kapita yang merupakan total pendapatan di suatu wilayah atau daerah dibagi dengan jumlah penduduknya untuk tahun yang sama. Singkatnya, yang menjadi masalah adalah melebarnya ketimpangan ekonomi antar penduduk dalam masyarakat, yang tidak sepenuhnya dapat ditunjukkan hanya dengan menggunakan indeks gini ratio. Untuk mengatasinya, diperlukan adanya pengamatan yang lebih seksama di lapangan dan kebijakan yang bersifat affirmatif memihak kepada golongan miskin, terutama kepada mereka yang ada dipedesaan. ${ }^{8}$

Menurut pandangan ahli-ahli ekonomi klasik, ada 4 faktor yang mempengaruhi pertumbuhan ekonomi, yaitu: jumlah penduduk, jumlah stok barang-barang modal, luas tanah dan kekayaan alam, serta tingkat teknologi yang digunakan. Dalam teori pertumbuhan mereka, dimisalkan luas tanah dan kekayaan alam adalah tetap jumlahnya dan tingkat teknologi tidak mengalami perubahan. Berdasarkan kepada teori pertumbuhan ekonomi klasik yang baru diterangkan, dikemukakan suatu teori yang menjelaskan perkaitan di antara pendapatan per kapita dan jumlah penduduk. Teori tersebut dinamakan teori penduduk optimum. Teori pertumbuhan klasik dapat dilihat bahwa apabila terdapat kekurangan penduduk, produksi marjinal adalah lebih tinggi dari pada pendapatan per kapita. Akan tetapi apabila penduduk semakin banyak, hukum hasil tambahan yang semakin berkurang akan mempengaruhi fungsi produksi, yaitu produksi marjinal akan mulai mengalami penurunan. Oleh karenanya pendapatan nasional dan pendapatan per kapita menjadi semakin lambat pertumbuhannya. ${ }^{9}$

Teori trickle-down effect menjelaskan bahwa kemajuan yang diperoleh oleh sekelompok masyarakat akan sendirinya menetes ke bawah sehingga menciptakan lapangan kerja dan berbagai peluang ekonomi yang pada gilirannya akan

\footnotetext{
${ }^{7}$ Tarigan Robinson, Pengantar Ekonomi Makro, Jakarta, Salemba, 2012, hlm. 74.

${ }^{8}$ Ibid., hlm. 75.

${ }^{9}$ Mudrajad Kuncoro, Ekonomi Pembangunan dan Perencanaan, Jakarta, Rajawali Press, hlm. 101.
} 
menumbuhkan berbagai kondisi demi terciptanya distribusi hasil-hasil pertumbuhan ekonomi yang merata. Teori tersebut mengimplikasikan bahwa pertumbuhan ekonomi akan diikuti oleh aliran vertikal dari penduduk kaya kependuduk miskin yang terjadi dengan sendirinya. Manfaat pertumbuhan ekonomiakan dirasakan penduduk kaya terlebih dahulu, dan kemudian pada tahap selanjutnya penduduk miskin mulai memperoleh manfaat ketika penduduk kaya mulai membelanjakan hasil dari pertumbuhaan ekonomi yang telah diterimanya. ${ }^{10}$

Dengan demikian, maka pengaruh pertumbuhan ekonomi terhadap penurunan angka kemiskinan merupakan efek tidak langsung oleh adanya aliran vertikal dari penduduk kaya ke penduduk miskin. Hal ini berarti juga bahwa kemiskinan akan berkurang dalam skala yang sangat kecil bila penduduk miskin hanya menerimasedikit manfaat dari total manfaat yang ditimbulkan dari adanya pertumbuhan ekonomi. Kondisi ini dapat membuka peluang terjadinya peningkatan kemiskinan sebagai akibat dari meningkatnya ketimpangan pendapatan yang disebabkan oleh pertumbuhan ekonomi yang lebih memihak penduduk kaya dibanding penduduk miskin. ${ }^{11}$

Oleh sebab itu, maka dapat disimpulkan bahwa pertumbuhan ekonomi dapat berdampak positif bagi pengurangan kemiskinan bilamana pertumbuhan ekonomi yang terjadi berpihak pada penduduk miskin. Pertumbuhan ekonomi merupakan syarat keharusan bagi pengurangan kemiskinan, sedangkan syarat kecukupannya adalah pertumbuhan ekonomi tersebut harus efektif dalam mengurangi kemiskinan. Artinya, pertumbuhan hendaklah menyebardi setiap golongan pendapatan, termasuk di golongan penduduk miskin. Secara langsung, hal ini berarti pertumbuhan itu perlu dipastikan terjadi di sektor-sektor dimana penduduk miskin bekerja (pertanian atau sektoryang padat karya). Adapun secara tidak langsung, hal itu berarti diperlukan pemerintah yang cukup efektif meredistribusi manfaat pertumbuhan. ${ }^{12}$

Pertumbuhan ekonomi dan kemiskinan merupakan indikator pentinguntuk melihat keberhasilan pembangunan suatu Negara. Setiap negara akan berusaha keras untuk mencapai pertumbuhan ekonomi yang optimal dan menurunkan angka kemiskinan. Di banyak negara di Indonesia syarat utama bagi terciptanya penurunan kemiskinan adalah pertumbuhan ekonomi. Namun,kondisi di negaranegara berkembang termasuk Indonesia pertumbuhan ekonomi yang dicapai ternyata juga diiringi dengan munculnya permasalahan meningkatnya jumlah penduduk yang hidup dibawah garis kemiskinan. ${ }^{13}$

34.

${ }^{10}$ Boediono., Ekonomi Mikro : Seri Sinopsis Pengantar Ilmu Ekonomi, BPFE. Yogyakarta, 2002, hlm.

${ }^{11}$ http://psc.litbang.deptan.go.id/ind/pdf:files/PROS_2008_MAK3.pdf. akses 20 Februari 2008.

${ }^{12}$ Boediono., Ekonomi Mikro : Seri Sinopsis Pengantar Ilmu Ekonomi, BPFE. Yogyakarta, 2002, hlm.

${ }^{13}$ N. Gregori Mankiw, Teori Makro Ekonomi, Jakarta: Gelora Aksara Pratama, 2007, hlm. 72. 
Model pertumbuhan Solow dirancang untuk menunjukkan bagaimana pertumbuhan persediaan modal, pertumbuhan angkatan kerja, dan kemajuan teknologi berinteraksi dalam perekonomian, serta bagaimana pengaruhnya terhadap output barang dan jasa suatu negara secara keseluruhan. Analisis solow selanjutnya membentuk formula matematik untuk persamaan itu dan seterusnya membuat pembuktian secara kajian empiris untuk menunjukkan kesimpulan berikut: faktor terpenting yang mewujudkan pertumbuhan ekonomi bukanlah pertambahan modal dan pertambahan tenaga kerja. Faktor yang paling penting adalah kemajuan teknologi dan pertambahan kemahiran dan kepakaran tenaga kerja. ${ }^{14}$

Berdasarkan data yang diperoleh maka pertumbuhan ekonomi di Propinsi Jambi 2013 yang diukur dari kenaikan Produk Domestik Regional Bruto (PDRB) atas dasar harga konstan 2000 meningkat $7.88 \%$ dari tahun sebelumnya. Kepala Badan Pusat Statistik (BPS) Provinsi Jambi, Yos Rusdiansyah menguraikan besaran PDRB Jambi 2013 atas dasar harga berlaku mencapai Rp 85.56 triliun, sedangkan atas dasar harga konstan tahun 2000 mencapai Rp 21,08 triliun dari Rp 20,37 triliun di 2012. Adapun sumber utama yang memberikan kontribusi pertumbuhan ekonomi dari sektor perdagangan, hotel dan restoran (PHR) $2.21 \%$, diikuti pertanian $2.18 \%$, dan sektor konstruksi $1.05 \%$. Semua sektor ekonomi yang membentuk PDRB tahun 2013 mengalami pertumbuhan positif, pertumbuhan tertinggi di sektor konstruksi dengan nilai dan laju $20.73 \%$, tapi hanya memberikan konstribusi $1.05 \%$. Sedangkan pertumbuhan ekonomi di triwulan IV-2013 yang digambarkan oleh PDRB meningkat 1,94 \% dibanding triwulan sebelumnya. Peningkatan juga datang dari sektor perdagangan, hotel dan restoran sebesar 4.78 $\%$ diikuti sektor pengolahan, jasa-jasa $3.34 \%{ }^{15}$

Adapun hasil survei berdasarkan perkembangan pertumbuhan ekonomi di Propinsi Jambi tahun 2009-2013 dapat dilihat pada grafik berikut ini :

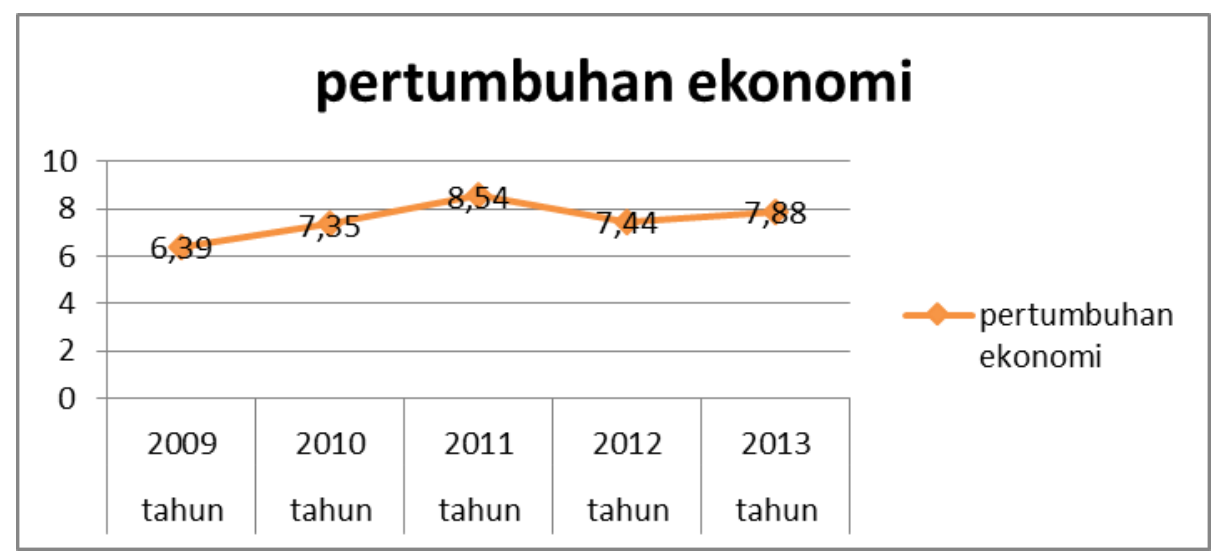

Dari data yang diperoleh berdasarkan perkembangan pertumbuhan ekonomi di Propinsi Jambi, $6.39 \%$ tahun 2009, $7.35 \%$ tahun 2010, 8.54 \% tahun 2011, 7.44

\footnotetext{
${ }^{14}$ Ibid., hlm. 72.

${ }^{15}$ Data dari Badan Pusat Statistik dan Informasi Kemiskinan Kabupaten/Kota Propinsi Jambi tahun 2012.
} 
\% tahun 2012 dan $7.88 \%$ tahun 2013. Dengan demikian, angka persentase pertumbuhan ekonomi paling tinggi adalah pada tahun 2011 yaitu $8.54 \%$ dan angka persentase yang paling rendah pada tahun 2009 yaitu 6.39\% (Data dari Badan Pusat Statistik dan Informasi Kemiskinan Kabupaten/Kota Propinsi Jambi tahun 2012).

Kondisi perekonomian yang membaik juga membawa dampak positif dalam penurunan tingkat kemiskinan. Selama periode 2009-2013 kemiskinan di Propinsi Jambi berkurang sebanyak $1.93 \%$. Kemiskinan di perkotaan Jambi lebih besar daripada di pedesaan. Ada kemungkinan yang menjelaskan hal ini, seperti tidak tersedianya klasifikasi lapangan kerja yang memadai dan besarnya tingkat urbanisasi. Hal ini menandakan belum berkembangnya lapangan kerja non pertanian di perkotaan, atau kondisi yang berkaitan dengan pertumbuhan penduduk di perkotaan dan daerah sekitar perkotaan yang relatif pesat. Jika pertambahan penduduk ini bersumber dari migrasi, maka kemungkinan berikutnya adalah tidak selarasnya antara keterampilan kerja para migran dan tingginya kompetisi memperebutkan lapangan kerja yang terbatas di perkotaan. ${ }^{16}$

Adapun hasil survei berdasarkan perkembangan kemiskinan di Propinsi Jambi tahun 2009-2013 dapat dilihat pada grafik berikut ini :

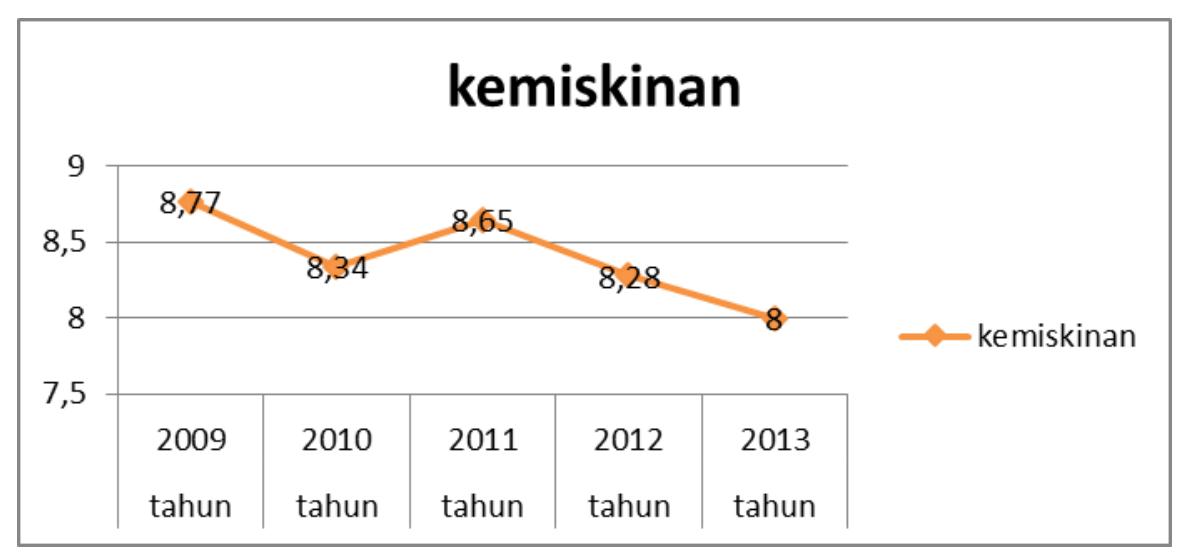

Dari data yang diperoleh berdasarkan perkembangan kemiskinan di Propinsi Jambi, $8.77 \%$ tahun 2009, $8.34 \%$ tahun 2010, $8.65 \%$ tahun 2011, $8.28 \%$ tahun 2012 dan $8.00 \%$ tahun 2013. Dengan demikian, angka persentase kemiskinan paling tinggi adalah pada tahun 2009 yaitu $8.77 \%$ dan angka persentase yang paling rendah pada tahun 2013 yaitu $8.00 \% .{ }^{17}$

Pada dasarnya, kemiskinan merupakan persoalan klasik yang telah ada sejak umat manusia ada. Kemiskinan merupakan persoalan kompleks, berwajah banyak, dan tampaknya akan terus menjadi persoalan aktual dari masa ke masa. Meskipun sampai saat ini belum ditemukan suatu rumusan ataupun formula penanganan

${ }^{16}$ Data dari Badan Pusat Statistik dan Informasi Kemiskinan Kabupaten/Kota Propinsi Jambi tahun

${ }^{17}$ Data dari Badan Pusat Statistik dan Informasi Kemiskinan Kabupaten/Kota Propinsi Jambi tahun 2012. 
kemiskinan yang dianggap paling berdayaguna, signifikan, dan relevan, pengkajian konsep dan strategi penanganan kemiskinan harus terus menerus diupayakan. Pengupayaan tersebut tentu sangat berarti sehingga kemiskinan tidak lagi menjadi masalah dalam kehidupan manusia. ${ }^{18}$

Tidak dapat dipungkiri bahwa kemiskinan merupakan masalah yang mencul ketika seseorang atau sekelompok orang tidak mampu mencukupi kebutuhan hidupnya. Rendahnya tingkat kehidupan yang sering menjadi masalah dalam suatu Propinsi sehingga dapat menimbulkan sebuah rantai kemiskinan. Ada berbagai pendapat yang mengemukakan tentang kemiskinan diantaranya bahwa kemiskinan berhubungan dengan kekurangan materi, rendahnya penghasilan dan adanya kebutuhan sosial. Sehingga kelompok miskin adalah dimana seseorang tidak dapat memenuhi kebutuhannya karena rendahnya penghasilan. Secara sederhana dan yang umum dapat dibedakan menjadi dua pengertian. Pertama, kemiskinan absolut yaitu seseorang yang hasil pendapatannya berada di bawah garis kemiskinan dan tidak cukup untuk menentukan kebutuhan dasar hidupnya. Kedua, kemiskinan relatif adalah seseorang yang telah dapat memenuhi kebutuhan dasar hidupnya, tetapi masih jauh lebih rendah dibandingkan dengan keadaan masyarakat sekitamya.

Dengan melihat lebih dekat permasalahan yang dihadapi pada semua daerah termasuk Propinsi Jambi adalah kemiskinan yang terjadi disebabkan kurangnya pendapatan karena sulit mendapatkan pekerjaan yang upahnya dapat memenuhi kebutuhan. Faktor pendidikan juga sangat berpengaruh terhadap tingkat kemiskinan. Semakin tinggi tingkat pendidikan seseorang maka semakin tinggi tingkat keahliannya, sehingga perusahaan tempatnya bekerja memperoleh keuntungan dari hasil yang dikerjakan dan akan memberikan bayaran yang mahal. Dan semakin sejahteralah hidup mereka yang berpendidikan tinggi. Sangat berbeda bagi mereka yang berpendidikan rendah, dengan keahlian yang dimiliki sangat minim sehingga jarang ada perusahaa yang mau untuk menerima bekerja. Pada saat ini sangat perlu diadakan penanggulangan-penanggulangan untuk menagatasi atau mengurangi tingkat kemiskinan di Propinsi Jambi untuk menaikkan kesejahteraan hidup masyarakat dan untuk menjadikan Propinsi Jambi semakin lebih baik lagi. ${ }^{19}$

Masalah kemiskinan merupakan persoalan yang senantiasa menghantui dari zaman pemerintahan yang satu dan beralih ke zaman pemerintahan berikutnya, bahkan sampai sekarang. Permasalahan kemiskinan tidak akan benar tertutup dan akan terus muncul jika pemerintah dan dengan bantuan kita semua tidak lebih giat lagi memberantasnya. Di berbagai buku sastra ekonomi bahkan menyebut tujuan penting dari ekonomi adalah untuk menghapus kemiskinan. Apa yang dimaksud miskin disini adalah ketidakmampuan seseorang untuk memenuhi kebutuhan hidupnya. Kemiskinan adalah keadaan dimana terjadi ketidakmampuan untuk memenuhi dasar seperti makanan, pakaian, tempat berlindung, pendidikan, dan

\footnotetext{
${ }^{18}$ N. Gregori Mankiw, Teori Makro Ekonomi, Jakarta: Gelora Aksara Pratama, 2007, hlm. 80.

${ }^{19}$ Data dari Badan Pusat Statistik dan Informasi Kemiskinan Kabupaten/Kota Propinsi Jambi tahun 2012.
} 
kesehatan. Dari pendapat diatas dapat disimpulkan bahwa kemiskinan merupakan akibat dari terjadinya ketimpangan atau ketidaksama rataan dalam pendistribusian pendapatan masyarakat sehingga ada yang berpenghasilan tinggi dan berpenghasilan rendah. ${ }^{20}$

Sebagaimana yang kita ketahui, negara Indonesia masih memiliki banyak warga negara yang miskin. Warga negara yang miskin membutuhkan sekali modal untuk dapat meningkatkan kesejahteraan hidupnya. Di dalam ajaran Islam, terdapat instrumen ekonomi yang dapat mengentaskan kemiskinan dan menciptakan pertumbuhan ekonomi yaitu zakat, infaq, dan shadaqah. Zakat didistribusikan kepada 8 golongan yaitu orang-orang fakir, miskin, petugas zakat (amil), muallaf (biasa diterjemahkan orang yang baru masuk Islam), budak, orang yang berutang dan tidak mampu membayar, musafir dan fi sabilillah. Ketika zakat dibagikan khususnya kepada orang fakir dan miskin, pengelolaan dana zakat tersebut harus diarahkan untuk kegiatan yang bersifat produktif. Dana zakat yang diarahkan kepada kegiatan yang bersifat produktif menjadi modal bagi orang fakir dan miskin untuk melakukan kegiatan kewirausahaan. Dalam menjalankan kegiatan kewirausahaannya, orang fakir dan miskin harus mencontoh Rasulullah SAW. Rasulullah melalui tuntunan Al Quran dan teladan Sunnah Nabawiyyah senantiasa menegaskan agar kita memiliki keyakinan yang tinggi dalam meraih keberhasilan ekonomi.

Namun demikian, esensi dari pertumbuhan ekonomi dalam Islam ialah tidak hanya meningkatnya GDP suatu negara tetapi juga yang lebih penting lagi ialah berkurangnya orang-orang miskin di suatu daerah dan terciptanya peningkatan kesejahteraan hidup secara merata bagi seluruh daerah khususnya para fakir dan miskin. ${ }^{21}$ Beberapa Faktor yang dapat mempengaruhi pertumbuhan ekonomi, diantaranya seperti di bawah ini:

a. Faktor sumber daya manusia (SDM).

Sumber daya manusia adalah suatu faktor yang penting karena dapat mempengaruhi pertumbuhan ekonomi. Karena SDM merupakan faktor yang penting dalam proses pembangunan, cepat atau lambatnya proses dari pembangunan sangat tergantung pada sumber daya manusianya yang selaku sebagai subjek pembangunan yang mempunyai kompetensi yang baik dan cukup memadai untuk melaksanakan proses dari pembangunan tersebut.

b. Faktor sumber daya alam (SDA).

SDA atau sumber daya alam merupakan faktor yang tidak kalah pentingnya dalam pembangunan atau pertumbuhan ekonomi, karena umumnya negara yang sedang dalam tahap perkembangan sangat bergantung pada sumber daya alam dalam pembangunan negaranya. Akan tetapi jika bergantung pada sumber daya

\footnotetext{
${ }^{20}$ Rusdarti Sebayang dan Lesta Karolina, Faktor-Faktor yang Mempengaruhi Tingkat Kemiskinan Di Provinsi Jawa Tengah, Jurnal Economia, Volume 9, Nomor, Jakarta 2013, hlm. 54.

${ }^{21}$ Ibid., hlm. 55.
} 
alam saja tidak akan menjamin kesuksesan dalam proses pembangunan atau pertumbuhan ekonomi, jika tidak di dukung dengan kemampuan SDM (Sumber daya manusia) dalam mengelola SDA (sumber daya alam) yang ada. Sumber daya alam misalnya seperti: kesuburan tanah, kekayaan akan mineral, kekayaan tambang, hasil alam, laut dan lain sebagainya.

c. Faktor Ilmu Pengetahuan dan Teknologi (IPTEK).

Perkembangan ilmu pengetahuan semakin kesini semakin pesat khususnya di bidang teknologi, hal tersebut dapat mempengaruhi pembangunan atau pertumbuhan ekonomi suatu negara, misalnya penggantian dalam menproduksi barang yang asalnya menggunakan tenaga manusia sekarang sudah banyak yang menggunakan mesin yang canggih dan modern yang tentunya akan lebih efesian dan lebih cepat dalam menghasilkan produk, yang pada akhirnya akan mempercepat pertumbuhan ekonomi dan pembangunan.

d. Faktor budaya.

Faktor yang penting lainnya yaitu faktor budaya, faktor ini akan memberikan dampak terhadap pertumbuhan ekonomi karena memiliki fungsi sebagai pendorong proses pembangunan misalnya seperti kerja keras, bersikap jujur, sopan, dan lain-lain. Akan tetapi faktor ini bisa juga menghambat proses pembangunan atau pertumbuhan ekonomi misalnya seperti sikap egois, anarkis, dan sebagainya.

e. Sumber daya modal.

Faktor yang terakhir adalah sumber daya modal, faktor ini sangatlah dibutuhkan manusia dalam mengelola Sumber Daya Alam (SDA) dan meningkatkan kualitas dari Ilmu Pengetahuan Dan Teknologi (IPTEK). Sumber daya modal ini misalnya berupa barang yang penting untuk perkembangan serta kelancaran dalam pembangunan ekomomi, sebab barang modal ini juga bisa meningkatkan dan memperbaiki produksi. ${ }^{22}$

Pertumbuhan ekonomi bisa diartikan sebagai perkembangan kegiatan dalam perekonomian yang menyebabkan barang dan jasa yang diproduksi dalam masyarakat bertambah. Dalam praktik, pertumbuhan ekonomi dihitung degan membandingkan Produk Domestik Bruto (PDB) tahun tertentu dengan PDB tahun sebelumnya. Produk Domestik Bruto (PDB) adalah jumlah nilai barang dan jasa yang dihasilkan seluruh masyarakat di suatu negara selama satu tahun, termasuk yang dihasilkan oleh warga negara asing yang ada di wilayah negara tersebut.

Oleh karena itu, pertumbuhan ekonomi bisa pula diartikan sebagai suatu keadaan perekonomian yang menunjukkan adanya kenaikan PDB (Produk Domestik Bruto) bila dibanding dengan tahun sebelumnya. Setiap negara atau pemerintah pasti menginginkan tercapainya pertumbuhan ekonomi yang optimal,

\footnotetext{
${ }^{22}$ Sadono Sukirno., Pengantar Teori Ekonomi : Pendekatan kepada Teori Ekonomi Mikro dan Makro, Jakarta, Rajawali, 2006, hlm. 54.
} 
sesuai dengan potensi yang dimiliki negara tersebut. Akan tetapi yang umumnya sering terjadi pertumbuhan ekonomi tidak tercapai secara optimal.Untuk itu perhatikan kurva kemungkinan produksi disamping.

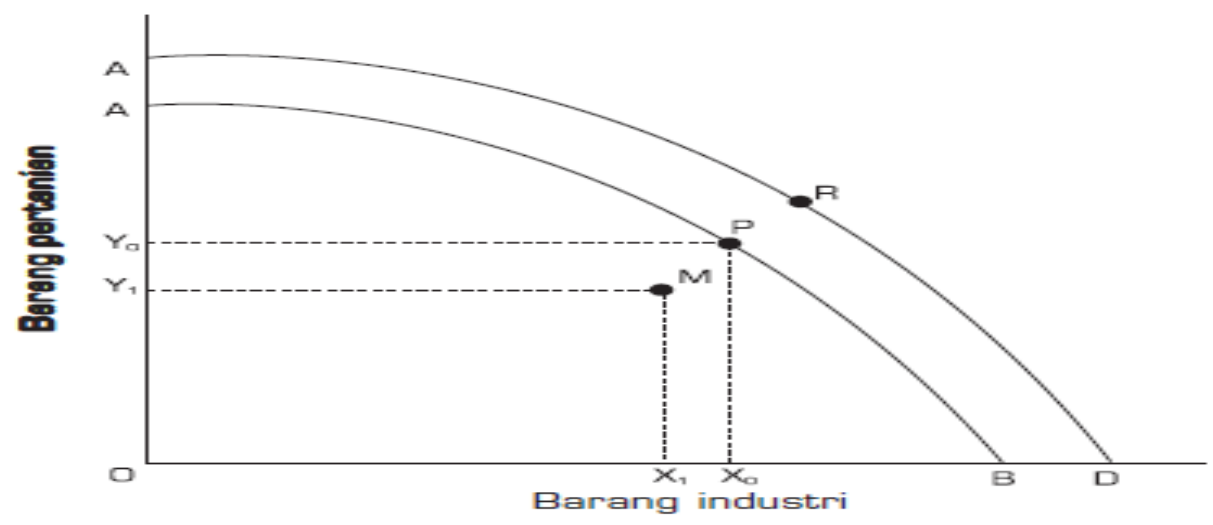

Kurva AB merupakan kurva yang menggambarkan batas maksimum produksi yang dapat diciptakan suatu negara pada waktu tertentu.Pada negara yang kurva batas maksimum produksinya adalah AB, kemakmuran masyarakat bisa tercapai secara maksimum bila kombinasi produksi barang industri dan barang pertanian adalah seperti yang ditunjukkan oleh salah satu titik pada kurva $A B$, misalnya oleh titik P. Titik P menunjukkan bila negara ingin memaksimumkan kemakmuran masyarakat, negara harus menghasilkan $\mathrm{X} 0$ barang industri dan $\mathrm{Y} 0$ barang pertanian. Pada waktu berikutnya, faktor-faktor produksi yang bertambah dan teknologi yang semakin maju telah memungkinkan negara tersebut memproduksi lebih banyak. Hal ini digambarkan oleh perubahan kurva dari AB ke CD. Dan titik $\mathrm{R}$ merupakan contoh kombinasi produksi barang industri dan barang pertanian bila negara ingin mencapai kemakmuran maksimum. Ini berarti, secara potensial negara tersebut dapat menaikkan produksi dalam perekonomian dari kombinasi P menjadi R. Tetapi dalam kenyataannya, kombinasi yang dicapai hanya dari M ke N. Dengan demikian, dapat dikatakan bahwa pertumbuhan ekonomi yang sebenarnya terjadi ternyata lebih lambat dari pertumbuhan ekonomi yang secara potensial dapat dilakukan. Akibatnya, sebagian faktor-faktor produksi terpaksa menganggur. ${ }^{23}$

Selama periode 2009-2013 kinerja perekonomian Propinsi Jambi relatif baik. Perekonomian daerah tumbuh dengan laju rata-rata $7.18 \%$ per tahun, di atas laju pertumbuhan rata-rata nasional sebesar $5.90 \%$ per tahun pada periode yang sama Dalam perekonomian wilayah Sumatera, Jambi berkontribusi sebesar $4.5 \%$ pada tahun 2012. Secara nasional, peran Jambi relatif masih kecil, namun meningkat dari 0.8 \%pada tahun 2009 menjadi $1 \%$ pada tahun 2010 dan meningkat kembali sebesar $1.08 \%$ pada tahun 2012. Komoditas unggulan Propinsi Jambi dalam bidang pertanian antara lain karet, kelapa sawit, dan kelapa. Meskipun laju pertumbuhan ekonomi daerah di atas laju nasional, namun secara per kapita laju

\footnotetext{
${ }^{23}$ N. Gregori Mankiw, Teori Makro Ekonomi, Jakarta: Gelora Aksara Pratama, 2007, hlm. 81.
} 
pertumbuhannya masih di bawah nasional karena laju pertumbuhan penduduk Propinsi Jambi yang relatif pesat. Karena tingginya laju pertumbuhan penduduk ini maka pertumbuhan perekonomian belum mampu memperkecil gap/kesenjangan PDRB per kapita antara Jambi dan rata-rata nasional PDB per kapita. Jika pada tahun 2006 rasio PDRB per kapita antara Jambi dan rata-rata nasional adalah 62.38 \% maka pada tahun 2012 rasionya meningkat menjadi 66.39\%. Hal ini berarti secara per kapita, perekonomian Jambi bertumbuh relatif cepat dibandingkan ratarata Propinsi lain. ${ }^{24}$

Untuk menjelaskan rasio dan ukuran indikator utama kemiskinan menurut Badan Perencanaan Pembangunan Nasional/BAPPENAS dapat dilihat dari; (1) kurangnya pangan, sandang dan perumahan yang tidak layak; (2) terbatasnya kepemilikan tanah dan alat-alat produktif; (3) kurangnya kemampuan membaca dan menulis; (4) kurangnya jaminan dan kesejahteraan hidup; (5) kerentanan dan keterpurukan dalam bidang sosial dan ekonomi; (6) ketakberdayaan atau daya tawar yang rendah; (7) akses terhadap ilmu pengetahuan yang terbatas. ${ }^{25}$

Objektif nilai kemiskinan ketentuannya adalah ketidakmampuan untuk memenuhi kebutuhan dasar seperti makanan, pakaian, tempat berlindung, pendidikan dan kesehatan. Kemiskinan dapat disebabkan oleh kelangkaan alat pemenuh kebutuhan dasar ataupun sulitnya akses terhadap pendidikan dan pekerjaan. Kemiskinan merupakan masalah global. Sebagian orang memahami istilah ini secara subyektif dan komparatif, sementara yang lainnya melihat dari segi moral dan evaluatif, dan yang lainnya lagi memahaminya dari sudut ilmiah yang telah mapan. Seseorang yang tergolong miskin relatif sebenarnya telah hidup di atas garis kemiskinan, namun masih berada di bawah kemampuan masyarakat sekitarnya. ${ }^{26}$

Tingkat kemiskinan menurut Badan Pusat Statistik (BPS) adalah presentase penduduk yang berada dibawah garis kemiskinan di masing-masing kabupaten/kota di Provinsi jambi.Garis kemiskinan yang merupakan dasar perhitungan jumlah penduduk miskin ditentukan dua kriteria yaitu pengeluaran konsumsi perkapita perbulan yang setara dengan 2100 kalori perkapita per hari dan nilai kebutuhan minimum komoditi bukan makanan. ${ }^{27}$

Secara sosio ekonomis terdapat dua bentuk kemiskinan, yaitu :

a. Kemiskinan absolut

Kemiskinan absolut adalah suatu kemiskinan di mana orang-orang miskin memiliki tingkat pendapatan dibawah garis kemiskinan, atau jumlah

\footnotetext{
${ }^{24}$ http://psc.litbang.deptan.go.id/ind/pdf:files/PROS_2008_MAK3.pdf.2008.Data dari Badan Pusat Statistik dan Informasi Kemiskinan Kabupaten/Kota Propinsi Jambi tahun 2008.

${ }^{25}$ Boediono., Ekonomi Mikro : Seri Sinopsis Pengantar Ilmu Ekonomi, BPFE. Yogyakarta, 2002, hlm. 55.

${ }^{26}$ Ismanto., Kemiskinan di Indonesia dan Program IDT, Centre For Strategic and International Studies, Jakarta: PPM, 2002, hlm. 55.

${ }^{27}$ Data dokumentasi Badan Puasat Statistik Jambi. BPS.go.id akses 20 September 2012.
} 
pendapatannya tidak cukup untuk memenuhi kebutuhan hidup minimum, kebutuhan hidup minimum antara lain diukur dengan kebutuhan pangan, sandang, kesehatan, perumahan dan pendidikan, kalori, GNP per kapita, pengeluaran konsumsi dan lain-lain.

b. Kemiskinan relatif

Kemiskinan relati adalah kemiskinan yang dilihat berdasarkan perbandingan antara suatu tingkat pendapatan dengan tingkat pendapatan lainnya. Contohnya, seseorang yang tergolong kaya (mampu) pada masyarakat desa tertentu bisa jadi yang termiskin pada masyarakat desa yang lain. ${ }^{28}$

Di samping itu terdapat juga bentuk-bentuk kemiskinan yang sekaligus menjadi faktor penyebab kemiskinan (asal mula kemiskinan). Ia terdiri dari: (1) Kemiskinan natural, (2) Kemiskinan kultural, dan (3) Kemiskinan struktural.

1) Kemiskinan Natural. Kemiskinan natural adalah keadaan miskin karena dari awalnya memang miskin.Kelompok masyarakat tersebut menjadi miskin karena tidak memiliki sumber daya yang memadai baik sumberdaya alam, sumberdaya manusia maupun sumber daya pembangunan, atau kalaupun mereka ikut serta dalam pembangunan, mereka hanya mendapat imbalan pendapatan yang rendah. Kemiskinan natural adalah kemiskinan yang disebabkan oleh faktor-faktor alamiah seperti karena cacat, sakit, usia lanjut atau karena bencana alam. ${ }^{29}$

2) Kemiskinan Kultural. Kemiskinan kultural adalah mengacu pada sikap hidup seseorang atau kelompok masyarakat yang disebabkan oleh gaya hidup, kebiasaan hidup dan budaya dimana mereka merasa hidup berkecukupan dan tidak merasa kekurangan. Kelompok masyarakat seperti ini tidak mudah untuk diajak berpartisipasi dalam pembangunan, tidak mau berusaha untuk memperbaiki dan merubah tingkat kehidupannya. Akibatnya tingkat pendapatan mereka rendah menurut ukuran yang dipakai secara umum. Hal ini sejalan dengan apa yang dikatakan bahwa ia miskin karena faktor budaya seperti malas, tidak disiplin, boros dan lain-lainnya. ${ }^{30}$

3) Kemiskinan Struktural. Kemiskinan sturktural adalah kemiskinan yang disebabkan oleh faktor-faktor buatan manusia seperti kebijakan ekonomi yang tidak adil, distribusi aset produksi yang tidak merata, korupsi dan kolusi serta tatanan ekonomi dunia yang cenderung menguntungkan kelompok masyarakat tertentu. Munculnya kemiskinan struktural disebabkan karena berupaya menanggulangi kemiskinan natural, yaitu dengan direncanakan bermacam-macam program dan kebijakan. Namun karena pelaksanaannya tidak seimbang, pemilikan sumber daya tidak merata, kesempatan yang tidak sama menyebabkan keikutsertaan masyarakat menjadi tidak merata pula,

\footnotetext{
${ }^{28}$ Ketut Sudhana Astika, Determinasi Keberadaan Pengemis Perkotaan di Kecamatan Denpasar Barat, Denpasar: Universitas Pendidikan Ganesha Singaraja, 2010, hlm. 77.

${ }^{29}$ Ismanto., Kemiskinan di Indonesia dan Program IDT, Centre For Strategic and International Studies, Jakarta: PPM, 2002, hlm. 57.

${ }^{30}$ Baswir., Ekonomi Pembangunan dan Perencanaan, Jakarta: Rajawali Press, 1995, hlm. 67.
} 
sehingga menimbulkan struktur masyarakat yang timpang. Hal ini disebut “accidental poverty”, yaitu kemiskinan karena dampak dari suatu kebijaksanaan tertentu yang menyebabkan menurunnya tingkat kesejahteraan masyarakat. ${ }^{31}$

Dalam pengertian yang lebih definitif, Syekh An-Nabhani mengategorikan yang punya harta, tetapi tak mencukupi kebutuhan pembelanjaannya sebagai orang fakir. Sementara itu, orang miskin adalah orang yang tak punya harta sekaligus tak punya penghasilan. Pembedaan kategori ini tepat untuk menjelaskan pengertian dua pos mustahiq zakat, yakni al-fuqara (orang-orang faqir) dan al-masakiin (orangorang miskin), sebagaimana firman-Nya yang artinya bahwa sesungguhnya zakatzakat itu, hanyalah untuk orang-orang fakir, orang-orang miskin, penguruspengurus zakat, Para mu'allaf yang dibujuk hatinya, untuk (memerdekakan) budak, orang-orang yang berhutang, untuk jalan Allah dan untuk mereka yuang sedang dalam perjalanan, sebagai suatu ketetapan yang diwajibkan Allah, dan Allah Maha mengetahui lagi Maha Bijaksana (QS at-Taubah [9]: 60). ${ }^{32}$

Kemiskinan atau kefakiran adalah suatu fakta, yang dilihat dari kacamata dan sudut manapun seharusnya mendapat pengertian yang sesuai dengan realitasnya. Sayang peradaban barat kapitalis, pengembang sistem ekonomi kapitalis, memiliki gambaran/fakta tentang kemiskinan yang berbeda-beda. Mereka menganggap bahwasannya kemiskinan adalah ketidakmampuan untuk memenuhi kebutuhankebutuhan atas barang ataupun jasa secara mutlak. Karena kebutuhan berkembang seiring dengan berkembang dan majunya produk-produk barang ataupun jasa, maka mereka menganggap usaha pemenuhan kebutuhan-kebutuhan atas barang dan jasa itu pun mengalami perkembangan dan perbedaan. ${ }^{33}$

Kemiskinan sebagai bagian dari penyebab kemiskinan merupakan pembenaran terhadap ketidakberdayaan atau kemalasan manusia. Di dalam $A l$ Quran Surat Allah SWT berfirman yang artinya bahwa sesunggubnya Dia-lah yang menjadikan orang tertawa dan menangis.Dan sesunggubnya Dia-lah yang mematikan dan menghidupkan. Dan sesunggubnya Dia-lah yang menciptakan pasangan laki-laki dan perempuan.-(QS An Najm 53: 43-46). Dan di ayat lain disebutkan juga dalam Al Quran Surat AN Najm 53: 48 bahwa Allah SWT memberikan kekayaan dan kecukupan yang artinya bahwa sesungguhnya Dia-lah yang memberikan kekayaan dan kecukupan. (Qs An Najm 53: 48).

Berkenaan dengan kemiskinan ini Allah SWT tidak mengatakan bahwa kemiskinan adalah dari-Nya, karena dengan sifat kasih dan sayang-Nya telah memberikan kekayaan dan kecukupan kepada umat manusia. Apabila terjadi kemiskinan, maka manusialah penyebabnya. Penyebab kemiskinan banyak dihubungkan dengan:

\footnotetext{
${ }^{31}$ Ibid., hlm. 67.

${ }^{32}$ Taqyuddin An-Nabhani, Membangun Sistem Ekonomi Alternatif: Perspektif Islam, Surabaya: Risalah Gusti, 2002, hlm. 50 .

${ }^{33}$ Ibid., hlm. 67.
} 
1) Penyebab individual, atau patologis, yang melihat kemiskinan sebaga iakibat dari perilaku, pilihan, atau kemampuan dari si miskin. Contoh dari perilaku dan pilihan adalah penggunaan keuangan tidak mengukur pemasukan.

2) Penyebab keluarga, yang menghubungkan kemiskinan dengan pendidikan keluarga. Penyebab keluarga juga dapat berupa jumlah anggota keluarga yang tidak sebanding dengan pemasukan keuangan keluarga.

3) Penyebab sub-budaya (subcultural), yang menghubungkan kemiskinan dengan kehidupan sehari-hari, dipelajari atau dijalankan dalam lingkungan sekitar. Individu atau keluarga yang mudah tergoda dengan keadaan tetangga.

4) Penyebab agensi, yang melihat kemiskinan sebagai akibat dari aksi orang lain, termasuk perang, pemerintah, dan ekonomi. Contoh dari aksi orang lain lainnya adalah gaji atau honor yang dikendalikan oleh orang atau pihak lain. Contoh lainnya adalah perbudakan.

5) Penyebab struktural, yang memberikan alasan bahwa kemiskinan merupakan hasil dari struktur sosial. Contohnya adalah sekelompok orang berada di dalam wilayah kemiskinan dan tidak ada peluang untuk keluar dari kemiskinan bahkan juga anak-anaknya, Bisa dikatakan kemiskinan abadi. ${ }^{34}$

Kondisi perekonomian yang membaik juga membawa dampak positif dalam penurunan tingkat kemiskinan. Selama periode 2006-2013 kemiskinan di Propinsi Jambi berkurang sebanyak 1,93 persen. Kemiskinan di perkotaan Jambi lebih besar dari pada di pedesaan. Ada beberapa kemungkinan yang menjelaskan.Hal ini menandakan belum berkembangnya lapangan kerja non pertanian di perkotaan, atau kondisi yang berkaitan dengan pertumbuhan penduduk di perkotaan dan daerah sekitar perkotaan yang relatif pesat. Jika pertambahan penduduk ini bersumber dari migrasi, maka kemungkinan berikutnya adalah tidak selarasnya antara ketrampilan kerja para migran dan tingginya kompetisi memperebutkan lapangan kerja yang terbatas di perkotaan. ${ }^{35}$

Untuk melihat hal tersebut perlu ada indikator pertumbuhan ekonomi kemiskinan. Pertumbuhan ekonomi kemiskinan adalah pertumbuhan ekonomi yang menunjukkan peningkatan secara fisik terhadap produksi barang dan jasa yang berlaku di suatu wilayah. Peningkatan ini dapat dilihat dari bertambahnya produksi barang industri, berkembangnya infrastruktur, bertambahnya produksi barang modal dan bertambahnya sektor jasa. Setiap wilayah akan selalu berusaha untuk mencapai pertumbuhan ekonomi yang optimal untuk membawa masyarakatnya kepada kehidupan yang lebih baik. Setiap pemerintahan akan mengukur keberhasilan perekonomian negaranya dengan berbagai metode atau indikator yang paling representatif terhadap perubahan perekonominya. ${ }^{36}$

\footnotetext{
${ }^{34}$ Ardi Hamzah., Tata Kelola Pemerintahan Desa Menuju Desa Mandiri, Sejahtera dan Parsipatoris, Surabaya, Pustaka, 2004, hlm .35.

${ }^{35} \mathrm{http}$ //daps.bps.go.id/FileBadanPusatStatistikJambi\%2000AnalisisKemiskinan.pdf diakses tanggal 26 Mei 2013.

${ }^{36}$ Hanafi, Manajemen Keuangan Internasional, Yogyakarta, BPFE, 2003, hlm 55.
} 
Adapun indikator-indikator pertumbuhan ekonomi kemiskinan adalah sebagai berikut:

a. Pendapatan nasional riil. Indikator pertama yang umum digunakan untuk menilai perkembangan ekonomi adalah perubahan pendapatan nasional riil dalam jangka waktu panjang. Pendapatan nasional riil menunjukkan output secara keseluruhan dari barang-barang jadi dan jasa suatu Negara. Negara dikatakan tumbuh ekonominya jika pendapatan nasional riil-nya naik dari periode sebelumnya. Tingkat petumbuhan ekonomi dihitung dari pertambahan pendapatan nasional riil yaitu Produk Nasional Bruto riil yang berlaku dari tahun ke tahun.

b. Pendapatan riil per kapita. Indikator kedua yang dapat digunakan untuk menilai perkembangan ekonomi adalah pendapatan riil per kapita dalam jangka waktu panjang. Ekonomi suatu Negara dikatakan tumbuh jika pendapatan masyarakatnya meningkat dari waktu kewaktu.

c. Kesejahteraan penduduk. Indikator ketiga yang juga digunakan untuk mengukur perkembangan ekonomi adalah nilai kesejahteraan penduduknya. Terjadi peningkatan kesejahteraan material yang terus-menerus dan berjangka panjang. Hal ini dapat ditinjau dari kelancaran distribusi barang dan jasa. Distribusi yang lancar menunjukkan distribusi pendapatan per kapita pada seluruh wilayah Negara. Peningkatan kesejateraan terjadi secara merata pada seluruh kawasan. Tingkat kesejahteraan dapat pula diukur dengan pendapatan riil per kapita.

d. Tenaga kerja dan pengangguran. Indikator keempat yang dapat digunakan untuk menilai pertumbuhan ekonomi adalah jumlah tenaga kerja dan tingkat pengangguran. Pengangguran merupakan selisih antara angkatan kerja dengan penggunaan tenaga kerja yang sebenarnya. Angkatan kerja adalah jumlah tenaga kerja yang terdapat dalam suatu perekonomian pada suatu waktu tertentu. Tenaga kerja dan pengangguran merupakan dua hal yang mempengaruhi pertumbuhan ekonomi. ${ }^{37}$

Secara deskriptor utama yang menjelaskan kemiskinan adalah terbatasnya kecukupan dan mutu pangan, terbatasnya akses dan rendahnya mutu layanan kesehatan, terbatasnya akses dan rendahnya mutu layanan pendidikan, terbatasnya kesempatan kerja dan berusaha, lemahnya perlindungan terhadap aset usaha, dan perbedaan upah, terbatasnya akses layanan perumahan dan sanitasi, terbatasnya akses terhadap air bersih, lemahnya kepastian kepemilikan dan penguasaan tanah, memburuknya kondisi lingkungan hidup dan sumberdaya alam, serta terbatasnya akses masyarakat terhadap sumber daya alam, lemahnya jaminan rasa aman, lemahnya partisipasi, besarnya beban kependudukan yang disebabkan oleh besarnya tanggungan keluarga, tata kelola pemerintahan yang buruk yang

${ }^{37}$ Sadono Sukirno., Pengantar Teori Ekonomi : Pendekatan kepada Teori Ekonomi Mikro dan Makro, Jakarta, Rajawali, 2006, hlm. 60. 
menyebabkan inefisiensi dan inefektivitas dalam pelayanan publik, meluasnya korupsi dan rendahnya jaminan social terhadap masyarakat. ${ }^{38}$

Kenyataan menunjukkan bahwa kemiskinan tidak bisa didefinisikan dengan sangat sederhana, karena tidak hanya berhubungan dengan kemampuan memenuhi kebutuhan material, tetapi juga sangat berkaitan dengan dimensi kehidupan manusia yang lain. Karenanya, kemiskinan hanya dapat ditanggulangi apabila dimensi-dimensi lain itu diperhitungkan. Sedangkan penyebab dasar kemiskinan adalah: kegagalan kepemilikan terutama tanah dan modal, terbatasnya ketersediaan bahan kebutuhan dasar, sarana dan prasarana, kebijakan pembangunan yang bias perkotaan dan bias sektor, adanya perbedaan kesempatan di antara anggota masyarakat dan sistem yang kurang mendukung, adanya perbedaan sumber daya manusia dan perbedaan antara sector ekonomi (ekonomi tradisional versus ekonomi modern), rendahnya produktivitas dan tingkat pembentukan modal dalam masyarakat, budaya hidup yang dikaitkan dengan kemampuan seseorang mengelola sumber daya alam dan lingkunganya, tidak adanya tata pemerintahan yang bersih dan baik (good governance), pengelolaan sumber daya alam yang berlebihan dan tidak berwawasan lingkungan. ${ }^{39}$

\section{TELAAH PUSTAKA}

Ada beberapa karya ilmiah dan penelitian-penelitian yang membahas mengenai pengaruh pertumbuhan ekonomi terhadap kemiskinan dan banyak di bahas oleh beberapa peneliti, baik yang dituangkan berupa buku maupun jurnaljurnal. Berikut ini ada beberapa jurnal yang telah meneliti tentang pengaruh pertubuhan ekonomi terhadap kemiskinan, yaitu sebagai berikut:

Dyah Arini Rudiningtyas dalam penelitiannya tentang Pengaruh Pendapatan dan Belanja terhadap Pertumbuhan Ekonomi, Kemiskinan dan Pengangguran (Studi pada APBN 2004-2008). Dalam penelitiannya menjelaskan tentang; yang pertama pendapatan dan belanja tidak berpengaruh terhadap tingkat pertumbuhan ekonomi selama tahun anggaran 2004 sampai 2008. Kedua, pendapatan dan belanja tidak berpengaruh terhadap kemiskinan selama tahun anggaran 2004 sampai 2008. Ketiga, pendapatan dan belanja tidak berpengaruh terhadap pengangguran selama tahun anggaran 2004 sampai 2008. Perbedaan penelitian ini tidak membahas tentang pengaruh pendapatan belanja. ${ }^{40}$

Dalam penelitian yang dilakukan oleh Sri Koncoro tentang Analisis Pengaruh Pertumbuhan Ekonomi, Tingkat Pengangguran dan Pendidikan

\footnotetext{
${ }^{38}$ Guritno, Ekonomi Pembangunan dan Perencanaan, Jakarta: Rajawali Pers, 2001, hlm 36.

${ }^{39}$ Lincolin Arsyad., Prospek Ekonomi Indonesia Jangka Pendek: Sumber Daya, Teknologi dan Pembangunan, Jakarta, Gramedia, 2001), hlm. 23.

${ }^{40}$ Dyah Arini Rudiningtyas., Pengaruh Pendapatan dan Belanja Terhadap Pertumbuhan Ekonomi, Kemiskinan dan Pengangguran (Studi pada APBN 2004-2008), Jurnal Universitas Islam Malang/UNISMA, 2010.
} 
Terhadap Tingkat Kemiskinan di Propinsi Jawa Timur tahun 2009-2011 yang pembahasan dalam penelitiannya adalah memfokuskan pada analisis pengaruh tingkat pengangguran dan pendidikan terhadap tngkat kemiskinan di propinsi Jawa Timur tahun 2009-2011, sedangkan penelitian yang dilakuan oleh peneliti pada pengaruh pertumbuhan ekonomi terhadap kemiskinan di Propinsi Jambi tahun 2009-2013 saja, didalam penelitian Sri Kuncoro pertumbuhan pendidikan juga di analisis sedangkan dalam penelitian ini tidak memasukan penelitian tentang pertumbuhan pendidikan. Persamaan dari penelitian Sri Kuncoro dan Penelitian yang dilakukan peneliti adalah sama-sama meneliti tentang pertumbuhan terhadap kemiskinan. ${ }^{41}$

Dalam Penelitian Barika tentang Pengaruh Pertumbuhan Ekonomi, Pengeluaran Pemerintah Pengangguran dan Inflasi terhadap Tingkat Kemiskinan di Propinsi Se-Sumatra. Hasil penelitiannya adalah secara umum tingkat kemiskinan propinsi di pulau Sumatera selama periode 2007-2011 menunjukan perbedaan yang cukup besar. Selama periode ini, propinsi Aceh merupakan daerah yang memiliki tingkat kemiskinan tertinggi yaitu mencapai 26,65\% di tahun 2007 dan menjadi $19,57 \%$ di tahun 2011. Hal ini dapat mengindikasikan bahwa kualitas pertumbuhan ekonomi yang terjadi relatif kurang baik yang antara lain disebabkan sebagian besar pertumbuhan ekonomi tersebut lebih ditopang oleh sektor konsumsi. Selain itu,kurang maksimalnya aspek pemerataan pendapatana dalam pertumbuhan ekonomi, sehingga peningkatan pendapatan cenderung dinikmati oleh sebagian kelompok masyarakat. Pengeluaran pemerintah dan tingkat pengangguran terbukti mempunyai pengaruh secara signifikan terhadap tingkat kemiskinan propinsi SeSumatra. Perbedaan antara penelitian yang di lakukan oleh Barika dengan penelitian yang dilakukan dalam penelitian ini adalah tempat penelitian. Penelitian yang dilakukan penulis disini hanya memfokuskan pada wilayah Propinsi Jambi, sedangkan penelitian yang dilakukan Barika melakukan penelitian tentang pengaruh pertumbuhan ekonomi, pengeluaran pemerintah pengangguran inflasi terhadap tingkat kemiskinan di Propinsi Se-Sumatra, dan juga penelitian Barika terdapat penambahan penelitian tentang pengaruh pengeluaran dan inflasi. Persamaannya juga membahas tentang pengaruh pertumbuhan ekonomi terhadap kemiskinan. ${ }^{42}$

\section{HASIL DAN PEMBAHASAN}

Untuk mengetahui ada atau tidaknya hubungan Pengaruh Pertumbuhan Ekonomi terhadap Kemiskinan di Propinsi Jambi Tahun 2009-2013, maka secara

${ }^{41}$ Sri Kuncoro., Analisis Pengaruh Pertumbuhan Ekonomi, Tingkat Pengangguran dan Pendidikan terhadap Tingkat Kemiskinan Di Propinsi Jawa Timur Tahun 2009-2011, Jurnal Unuversitas Muhamadiyah Surakarta, 2014.

${ }^{42}$ Barika., Pengaruh Pertumbuhan Ekonomi, Pengeluaran Pemerintah, Penganggruran dan Inflasi terhadap Tingkat Kemiskinan di Propinsi Se-Sumatera, Jurnal Universitas Muhamadiyah Surakarta, 2013. 
teoritis dapat diukur dengan menggunakan program bantu statistik SPSS sebagai berikut:

\section{Analisis Regresi Linier Sederhana}

Pengujian terhadap uji normalitas dapat dihasilkan dengan satu kesimpulan data yang benar atau layak.

a. Uji Normalitas

Uji Normalitas bertujuan untuk menguji apakah dalam sebuah regresi variabel dependen, variabel independen, atau keduanya mempunyai distribusi normal atau tidak. Suatu data dikatakan normal bila memiliki penyebaran atau distribusi data yang normal, untuk megetahui penyebaran data tersebut salah satu bentuk pengujian yang dapat digunakan adalah pendekatan kolmogorov Smirnov (K-S) Kreteria pengujinya adalah :

Pengujian normalitas dilakukan terhadap residul regresi.Pengujian dilakukan dengan menggunakan grafik P-P Plot Test. Data yang normal adalah data yang membentuk titik-titik yang menyebar tidak jauh dari garis diagonal. Hasil analisis regresi linier dengan grafik normal terhadap P-P Plot Test terhadap residual error model regresi diperoleh sudah menunjukan adanya polagrafik yang normal, yaitu adanya sebaran titik yang berada tidak jauh dari garis diagonal.

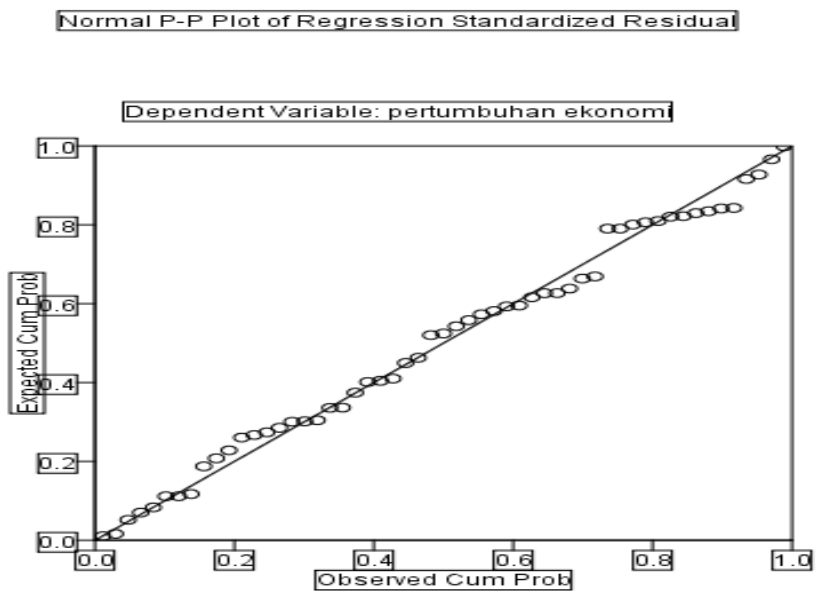

Hasil pengujian tersebut menunjukkan bahwa titik-titik berada tidak jauh dari garis diagonal. Hal ini menyatakan bahwa model regresi tersebut berdistribusi normal.

b. Uji $t$

Uji statistik $t$ atau test of significance digunakan untuk mengetahui apakah pengaruh variabel independen berpengaruh terhadap variabel dependen 
bersifat menentukan (significant) atau tidak, dengan kriteria berdasarkan nilai signifikan $<0.05$ maka variabel independen mempunyai pengaruh yang signifikan terhadap variabel dependen dan sebaliknya, jika nilai signifikannya $>0.05$. Maka variabel independen tidak mempunyai pengaruh yang signifikan terhadap variabel dependen.

Pengujian Hipotesis

\begin{tabular}{|l|l|l|l|l|l|}
\hline \multicolumn{1}{|c|}{ Variabel } & $\begin{array}{l}\text { Koeficien } \\
\text { regresi }\end{array}$ & $\begin{array}{l}\text { Std. } \\
\text { Error }\end{array}$ & t-test & Sig. & Keterangan \\
\hline Konstanta & 7.812 & .473 & 16.523 & 0.000 & \\
\hline Kemiskinan & -.099 & .054 & -1.839 & 0.072 & Signifikan \\
\hline
\end{tabular}

Berdasarkan hasil uji $t$ menunjukkan bahwa variabel tingkat kemiskinan memiliki nilai tidak signifikan yaitu sebesar 0,072, nilai ini lebih kecil dari 0,000, ini berarti $H_{o}$ di tolak. Sehingga dapat disimpulkan tingkat pertumbuhan ekonomi tidak berpengaruh signifikan terhadap kemiskinan, nilai kesatuan variabel inflasi terhadap kemiskinan bernilai negatif.

Hipotesis:

Ho: $\quad \beta i=0$, artinya pertumbuhan ekonomi tidak signifikan terhadap kemiskinan

Ha: $\beta i \neq 0$, artinya pertumbuhan ekonomi signifikan terhadap kemiskinan

Pengambilan keputusan :

1) Jika sig $<$ alpha $(\mathrm{sig}<0,05)$, maka $\mathrm{H}_{\mathrm{o}}$ di tolak dan $\mathrm{H}_{\mathrm{a}}$ diterima sehingga dapat disimpulkan bahwa variabel independen berpengaruh signifikan terhadap variabel dependen.

2) Jika sig $>(\operatorname{sig}>0,05) \mathrm{H}_{\mathrm{o}}$ diterima dan $\mathrm{H}_{\mathrm{a}}$ ditolak sehingga dapat disimpulkan bahwa variabel independen tidak berpengaruh signifikan terhadap variabel dependen.

Dari hasil analisis menunjukkan pertumbuhan ekonomi berkorelasi negatif terhadap tingkat kemiskinan di Propinsi Jambi. Hal ini berarti bahwa semakin meningkat pertumbuhan ekonomi di Propinsi Jambi, maka kemiskinan semakin menurun. Nilai koefisien pertumbuhan ekonomi sebesar 0.001 di mana ini berarti bahwa kenaikan pertumbuhan ekonomi sebesar 1 persen dapat menurunkan jumlah penduduk miskin sebesar 0,001 persen. Bila di lihat dari hasil pengujian terhadap nilai $t$ statisik diperoleh nilai 0.236 yang lebih besar dibandingkan dengan $t$ tabel $(\alpha 5 \%=0.000)$ di mana hal ini berari bahwa variabel pertumbuhan ekonomi tidak berpengaruh signifikan terhadap variabel kemiskinan. 
Berdasarkan hasil penelitian pertumbuhan ekonomi terbukti memberi dampak terhadap berkurangnya jumlah penduduk miskin. Kenaikan pertumbuhan ekonomi sebesar $1 \%$ ternyata dapat menurunkan jumlah penduduk miskin sebesar $0.0001 \%$. Hal tersebut mengindikasikan bahwa, berdasarkan data BPS selama periode 2009-2013 setelah melewati masa kritis ternyata pertumbuhan ekonomi yang dicapai Propinsi Jambi cukup siqnifikan dari sisi dampaknya terhadap pengurangan kemiskinan. Dampak peningkatan kontribusi dan daya serap tenaga kerja sektor pertanian dimana banyak terdapat kantong-kantong kemiskinan dapat mengurangi jumlah penduduk miskin. Di samping itu peningkatan penerapan teknologi hasil pertanian dapat meningkatkan produktivitas hasil pertanian dimana sebagian besar penduduk miskin menggantungkan hidupnya. Ketertinggalan dalam penguasaan teknologi menyebabkan produktivitas dan daya saing produk pertanian menjadi rendah sehingga pendapatan petani menjadi rendah. Dengan kenaikan produktivitas dan daya saing produk hasil pertanian akan meningkatkan harga jual produk yang lebih kompetitif, sehingga hal ini akan meningkatkan pendapatan petani dan mengeluarkan dari tingkat kemiskinan.

\section{KESIMPULAN}

Berdasarkan hasil penelitian, maka dapat diambil kesimpulan bahwa terdapat hubungan dua arah yang kuat antara pertumbuhan ekonomi dan kemiskinan di Propinsi Jambi tahun 2009-2013. Penelitian ini lebih menekankan pada pengaruh pertumbuhan ekonomi terhadap kemiskinan. Metode yang digunakan dalam penelitian ini adalah metode pendekatan kuantitatif. Analisa data yang digunakan adalah rumus pendapatan dan analisis statistik regresi linier sederhana dengan menggunakan variabel independen yang meliputi pertumbuhan ekonomi terhadap variabel dependen kemiskinan. Hasil penelitian menunjukkan bahwa pertumbuhan ekonomi tidak berpengaruh signifikan terhadap kemiskinan. Dari faktor tersebut volume pertumbuhan ekonomi tidak mempunyai pengaruh yang paling dominan terhadap kemiskinan karena memiliki nilai terbesar dibandingkan dengan nilai pertumbuhan. Hasil analisis yang menyebutkan bahwa perkembangan dan pertumbuhan ekonomi di Propinsi Jambi pada angka persentase pertumbuhan ekonomi dari tahun 2009-2013 yang paling tinggi adalah pada tahun 2011 dan yang paling rendah pada tahun 2009. Berdasarkan perkembangan kemiskinan di Propinsi Jambi bahwa angka persentase kemiskinan pada tahun 2009-2013 yang paling tinggi adalah pada tahun 2013 dan yang paling rendah pada tahun 2011. Pengaruh pertumbuhan ekonomi terhadap kemiskinan di Propinsi Jambi dimana variabel pertumbuhan ekonomi tidak ada pengaruh dan tidak signifikan terhadap variabel kemiskinan atau nilai kesatuannya terhadap kemiskinan bernilai negatif. Ini menunjukkan bahwa pertumbuhan ekonomi tidak berpengaruh terhadap kemiskinan di Propinsi Jambi. 


\section{DAFTAR PUSTAKA}

An-Nabhani, Taqyuddin., Membangun Sistem Ekonomi Alternatif: Perspektif Islam, Surabaya: Risalah Gusti, 2002.

Arsyad, Lincolin., Prospek Ekonomi Indonesia Jangka Pendek: Sumber Daya, Teknologi dan Pembangunan, Jakarta, Gramedia, 2001.

Astika, Ketut Sudhana., Determinasi Keberadaan Pengemis Perkotaan di Kecamatan Denpasar Barat, Denpasar: Universitas Pendidikan Ganesha Singaraja, 2010.

Boediono., Ekonomi Mikro : Seri Sinopsis Pengantar Ilmu Ekonomi, BPFE. Yogyakarta, 2002.

Baswir., Ekonomi Pembangunan dan Perencanaan, Jakarta: Rajawali Press, 1995.

Barika, "Pengaruh Pertumbuhan Ekonomi, Pengeluaran Pemerintah, Penganggruran dan Inflasi terhadap Tingkat Kemiskinan di Propinsi Se-Sumatera", Jurnal Universitas Muhamadiyah Surakarta, 2013.

Dokumentasi Badan Pusat Statistik Propinsi Jambi 2010.

Data Badan Pusat Statistik dan Informasi Kemiskinan Kabupaten/Kota Jambi, 2009.

Data Badan Pusat Statistik Jakarta. dan Informasi Kemiskinan Kabupaten/Kota, 2010.

Data Badan Pusat Statistik dan Informasi Kemiskinan Kabupaten/Kota Propinsi Tahun Jambi 2009-2013.

Guritno, Ekonomi Pembangunan dan Perencanaan, Jakarta: Rajawali Pers, 2001.

Hanafi, Manajemen Keuangan Internasional, Yogyakarta, BPFE, 2003.

Hamzah, Ardi., Tata Kelola Pemerintahan Desa Menuju Desa Mandiri, Sejabtera dan Parsipatoris, Surabaya, Pustaka, 2013.

Ismanto., Kemiskinan di Indonesia dan Program IDT, Centre For Strategic and International Studies, Jakarta: PPM, 2002.

Kuncoro, Mudrajad., Ekonomi Pembangunan dan Perencanaan, Jakarta, Rajawali Press, 2006.

Kuncoro, Sri., "Analisis Pengaruh Pertumbuhan Ekonomi, Tingkat Pengangguran dan Pendidikan terhadap Tingkat Kemiskinan Di Propinsi Jawa Timur Tahun 2009. 2011”, Jurnal Unuversitas Muhamadiyah Surakarta, 2014.

Mankiw, N. Gregory., Teori Makro EkonomiT, Jakarta: Gelora Aksara Pratama, 2003.

------------., Pengantar Ekonomi Makro, Bandung, Pustaka Setia, 2006.

Rudiningtyas, Dyah Arini Rudiningtyas., Pengarub Pendapatan dan Belanja Terhadap Pertumbuhan Ekonomi, Kemiskinan dan Pengangguran (Studi pada APBN 2004 2008), Jurnal Universitas Islam Malang/UNISMA, 2010. 
Soepeno, Bambang, Statistik Terapan, Jakarta, Rineka Cipta, 2002.

Sebayang, Rusdarti dan Lesta Karolina., Faktor-Faktor yang Mempengarubi Tingkat Kemiskinan Di Provinsi Jawa Tengah, Jurnal Economia, Volume 9, Nomor , Jakarta 2013.

Sugiyono, Statistik untuk Penelitian, Bandung, Alfabeta, 2005.

Sukirno Sadono., Pengantar Teori Ekonomi: Pendekatan kepada Teori Ekonomi Mikro dan Makro, Jakarta, Rajawali, 2006.

-------------., Pengantar Ekonomi Makro, Jakarta, Graha Media, 2010.

Tarigan, Robinson., Pengantar Ekonomi Makro, Jakarta, Salemba, 2012. 